\title{
The mechanism of the 1941 Tsaoling landslide, Taiwan: insight from a 2D discrete element simulation
}

\author{
Chao-Lung Tang $\cdot$ Jyr-Ching Hu $\cdot$ Ming-Lang Lin • \\ Ren-Mao Yuan $\cdot$ Ching-Chuan Cheng
}

Received: 1 January 2012/Accepted: 5 December 2012/Published online: 25 December 2012

(C) The Author(s) 2012. This article is published with open access at Springerlink.com

\begin{abstract}
Tsaoling is located in Southwestern Taiwan, $10 \mathrm{~km}$ east of the frontal thrusts of the mountain belt. Five large historical landslide events were recorded from 1862 to 1999. No details of the earliest landslide event (1862) are available, thus this paper deals with the 1941 landslide event. Using the Particle Flow Code in two dimensions (PFC 2D) to simulate the mechanism of the Tsaoling landslide in 1941, this study shows that the landslide block developed cracks and slid down $0.2-1.8 \mathrm{~m}$ on the sliding plane. The cracks concentrated in certain zones, which corresponded to future landslide detachment planes. During the vibration simulation, the cracks spread from the
\end{abstract}

Electronic supplementary material The online version of this article (doi:10.1007/s12665-012-2190-1) contains supplementary material, which is available to authorized users.

C.-L. Tang $(\bowtie) \cdot$ J.-C. Hu

Department of Geosciences, National Taiwan University,

Taipei, Taiwan

e-mail: d92224002@ntu.edu.tw

C.-L. Tang

Yong-Kang Elementary School, Tainan, Taiwan

J.-C. $\mathrm{Hu}$

Associated International Laboratory ADEPT, CNRS-NSC,

Taipei, Taiwan

\section{M.-L. Lin}

Department of Civil Engineering, National Taiwan University, Taipei, Taiwan

R.-M. Yuan

Institute of Geology China Earthquake Administration,

Beijing, China

C.-C. Cheng

Ba-Gua Elementary School, Kaohsiung, Taiwan shear plane to ground surface. Monitoring the variations of the displacements, velocity, and stress during vibration simulation showed that the peak velocity and stress in the transition zones occurred at $3 \mathrm{~s}$. The displacement of the left part of the block exceeded $1.3 \mathrm{~m}$, and the displacement of the right part was less than $1.3 \mathrm{~m}$ during vibration simulation. These results suggest that the left part of the block was pushed down by the right part, ultimately inducing a landslide during an earthquake.

Keywords Particle Flow Code (PFC) - Distinct element model $($ DEM) $\cdot$ Newmark displacement $\cdot$ Tsaoling landslide

\section{Introduction}

Large earthquakes in Southeastern Taiwan are relatively common historical occurrences. Tsaoling, which is located in Southwestern Taiwan, lies $10 \mathrm{~km}$ east of the frontal thrusts of the mountain belt. Tsaoling has experienced five large landslides in the nineteenth and twentieth centuries (Table 1). Previous studies on Tsaoling landslides (Kawada 1942; Chang 1951; Hsu 1951; Hsu and Leung 1977; Chang 1984; Hung et al. 2002; Chen et al. 2005) have revealed four characteristics of Tsaoling landslides: (1) they tend to reoccur, (2) multi-landslide surfaces, (3) huge landslide blocks, and (4) local people survived after sliding $2 \mathrm{~km}$. The last point suggests that the strata were not seriously disturbed and the uppermost strata remained on top during the landslide. The reoccurrence of Tsaoling landslides makes this area a good example for landslide studies. The kinematic process of repeated Tsaoling landslides remain poorly understood. The best way to understand the repeated Tsaoling landslides is to study the historical events in the 
Table 1 Summary of historical landslides in the Tsaoling area, Taiwan, 1862-1999

\begin{tabular}{|c|c|c|}
\hline Date & Trigger & Note \\
\hline June 6,1862 & Earthquake $(M=7.0)$ & Landslide; formation of a landslide dam \\
\hline $\begin{array}{r}\text { December } \\
17,1941\end{array}$ & Earthquake $(M=7.1)$ & $\begin{array}{l}\text { Landslide volume: } 84 \times 10^{6} \mathrm{~m}^{3} \text {. Landslide dam }(70-200 \mathrm{~m} \text { in height }) \text { was formed. } \\
\text { A dammed lake contained } 12.8 \times 10^{6} \mathrm{~m}^{3} \text { of water }\end{array}$ \\
\hline $\begin{array}{l}\text { August 10, } \\
1942\end{array}$ & $\begin{array}{l}\text { Rainfall: } 3 \text { days' cumulative } \\
\text { precipitation of } 770 \mathrm{~mm}\end{array}$ & $\begin{array}{l}\text { Landslide volume: } 100 \times 10^{6} \mathrm{~m}^{3} \text {. Landslide dam }(140-217 \mathrm{~m} \text { in height) formed. A larger } \\
\text { dammed lake containing } 157 \times 10^{6} \mathrm{~m}^{3} \text { of water, which falled on May } 18,1951 \text {, killing } \\
147 \text { people }\end{array}$ \\
\hline $\begin{array}{l}\text { August } 15 \\
1979\end{array}$ & $\begin{array}{l}\text { Rainfall: } 2 \text { days' cumulative } \\
\text { precipitation of } 327 \mathrm{~mm}\end{array}$ & $\begin{array}{l}\left.\text { Landslide volume: } 26 \times 10^{6} \mathrm{~m}^{3} \text {. A landslide dam ( } 90 \mathrm{~m} \text { in height }\right) \text { formed and a dammed } \\
\text { lake contained } 40 \times 10^{6} \mathrm{~m}^{3} \text { of water }\end{array}$ \\
\hline $\begin{array}{r}\text { September } \\
21,1999\end{array}$ & Chi-Chi Earthquake $\left(M_{\mathrm{L}}=7.3\right)$ & $\begin{array}{l}\text { Landslide volume: } 125 \times 10^{6} \mathrm{~m}^{3} \text {. A debris dam formed with a height of } 50 \mathrm{~m} \text { at upstream } \\
\text { and } 150 \mathrm{~m} \text { at downstream. Estimated storage capacity larger than } 46 \times 10^{6} \mathrm{~m}^{3}\end{array}$ \\
\hline
\end{tabular}

Tsaoling area. This study focuses on the 1941 landslide because no record was found for the 1862 landslide event and most of the landslide evidence has disappeared.

A landslide block is not a rigid body; in general it behaves as a quasi-rigid, body (Tang et al. 2009). Researchers frequently use the Particle Flow Code (PFC) model to analyze granular assemblages with purely frictional or bonded circular particles represented by discs. Numerical modeling based on the discrete element method is another powerful tool for modeling rock slope susceptibility to earthquakes. Because of its explicit solution in the time domain, this method is ideal for studying the time propagation of a stress wave or a ground vibration. Many studies on rock mechanics, rate-and-state friction behavior, and landslides have successfully used numerical applications of the discrete element method (Campbell et al. 1995; McDowell and Harireche 2002; Cheng et al. 2003; Potyondy and Cundall 2004; Taboada et al. 2005, 2006). This study investigates the kinematics and mechanical behavior of the Tsaoling landslide as constrained by the geometry and structure of the sliding mass before the 1941 event.

The 1941 Tsaoling landslide

On December 17, 1941, Taiwan was shaken by a strong earthquake occurring near Chiayi (Taipei Observatory 1942). The epicenter was located at $23.40^{\circ} \mathrm{N} / 120.50^{\circ} \mathrm{E}$, approximately $10 \mathrm{~km}$ southeast of Chiayi and $27.5 \mathrm{~km}$

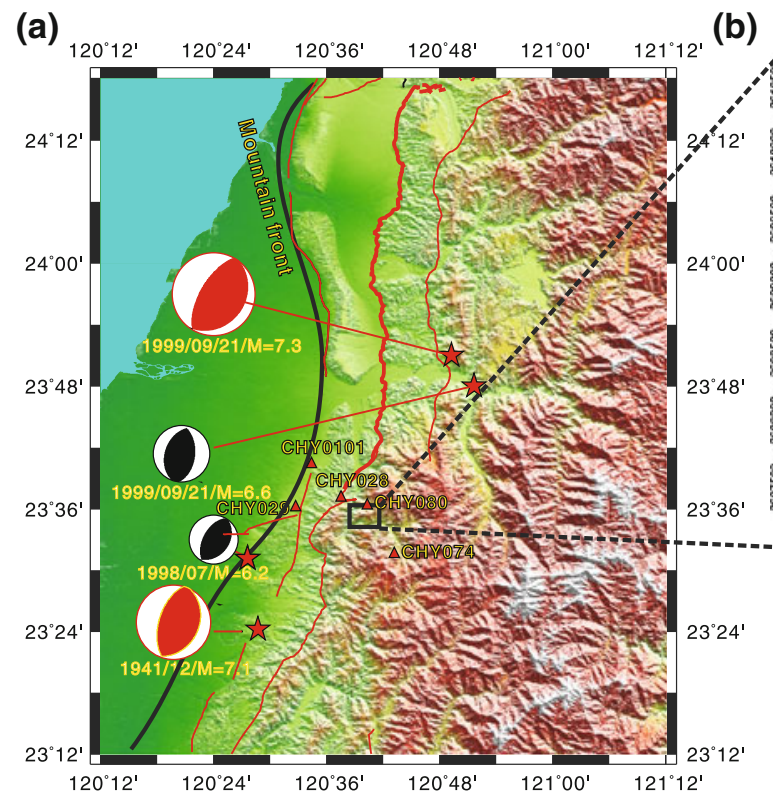

Fig. 1 Location, morphology, and geological setting of the Tsaoling area. a Location in West-Central Taiwan, the 4 historic epicenters are depicted as red stars, with the main shock focal mechanism shown as the beachball stereoplots (red triggered events, black no triggered). b Topographic and geological map of Tsaoling, with red lines

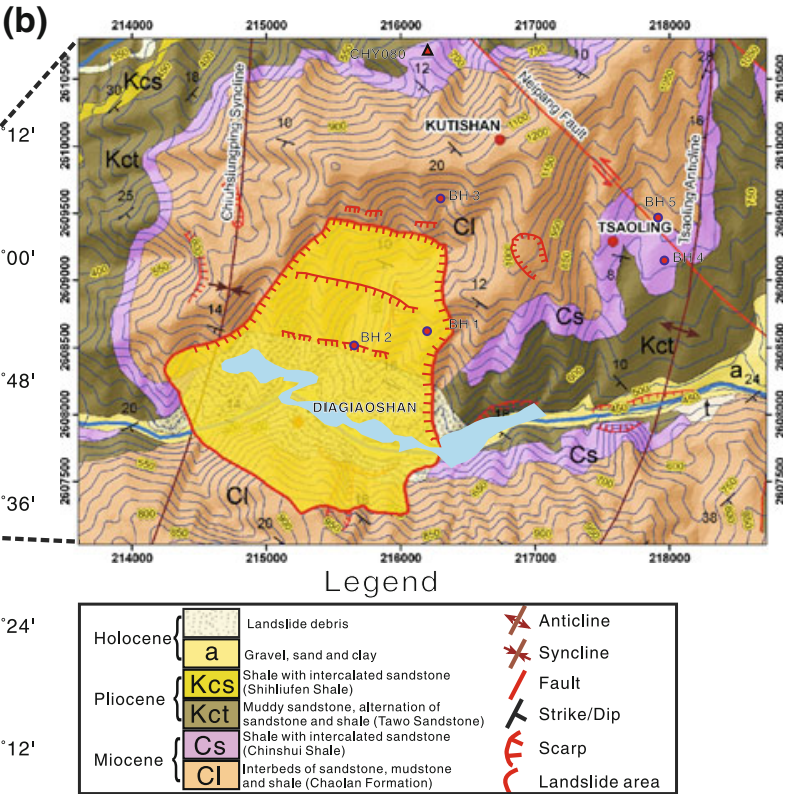

showing the extent of the scarp area (to the north) and accumulation area (to the south, in the Chinshui River valley, surrounding the landslide debris). The semi-transparent area represents the Tsaoling 1941 landslide area 
Fig. 2 Tsaoling historic landslide profile. Except for the 1979 landslide event, the landslides occurred in the Chaolan Formation

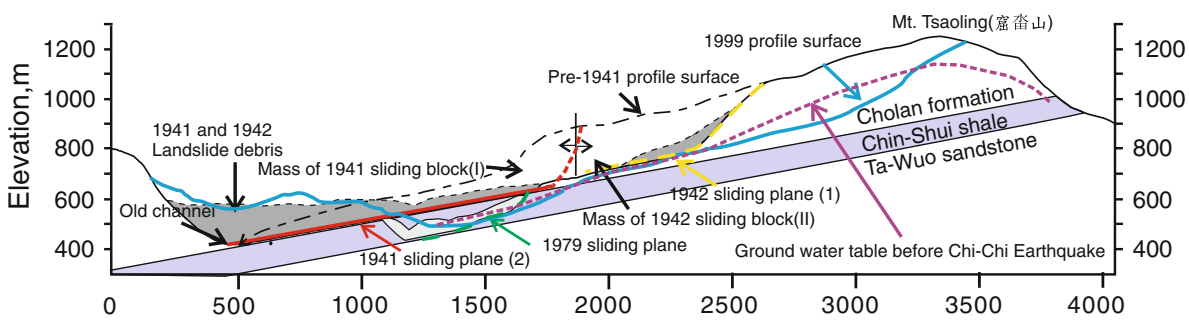

the slope is determined by the shear strength characteristics and unit weight of intact rock on a homogeneous slope.

Sliding analysis methods can be divided into static and dynamic equilibrium equations. Static equilibrium analysis, which involves using the limit equilibrium method, only examines the initiation of motion and does not consider the subsequent behavior of the whole system. The limit equilibrium method involves a single rock block or a system of blocks, assumes that the block is stiff, and is used only to analyze sliding phenomena (Wittke 1965; Goodman and Brey 1976; Chan and Einstein 1981; Lin and Fairhurst 1988). The distinct element method (DEM) and Newmark displacement (Newmark 1965) analysis use dynamic equilibrium equations to simulate the behavior of a blocky or particle system. These approaches assume a more realistic hypothesis by referring to real physical phenomena. The DEM provides an efficient procedure of dynamic analysis and can be used to examine the stability conditions of a blocky rock mass (Cundall 1971, 1988; Cundall and Hart 1985; Hart et al. 1988).

\section{Geological framework}

The Tsaoling area is located in the eastern part of Yulin County in Central Taiwan. Chingshui River, a tributary of Choshui River, meanders through the landslide area. The difference in elevation between the river (450 m elevation) and the surrounding peaks (1,234 $\mathrm{m}$ elevation) is approximately $800 \mathrm{~m}$, with an average valley width of $2 \mathrm{~km}$ (Fig. 1b). The average slope of the valley flanks is often as steep as $37.5 \%$.

\section{Geological setting of the Tsaoling area}

The Tsaoling area, which lies in the western foothills of Taiwan approximately $10 \mathrm{~km}$ east of the frontal thrusts of the mountain belt (Fig. 1a), is affected by major westvergent thrust faults (Angelier et al. 1986; Mouthereau et al. 2002). The bedrock of the Tsaoling area dates from the Pliocene and belongs to the upper part of the Chinshui Shale and the lower part of the Chaolan Formation (Fig. 1b). The Chinshui Shale did not outcrop before the 1941 landslide event. According to the field investigation by Lee et al. (1993), the Chinshui Shale in the landslide parallel to the slope surface and joint sets. The stability of 
area was not disturbed; therefore, the main landslide surface in 1941 was near the interface of the Chaolan Formation and the Chinshui Shale (Fig. 2).

From a lithological viewpoint, the Chinshui Shale consists mainly of massive mudstone and shale frequently intercalated with a fine- to very fine-grained sandstone layer. The Chaolan Formation, which is thicker than 1,000 $\mathrm{m}$ and rests on the Chinshui Shale, was the primary source of landslide debris. The Chaolan Formation consists of thick gray, muddy sandstone and slate-gray shale (Huang et al. 1983), which is divided into three layers: Chl (the lower part of the Chaolan Formation), Chm (the middle part of the Chaolan Formation), and Chu (the upper part of the Chaolan Formation). Chl consists of sandstone and thin shale, and is $25-30 \mathrm{~m}$ in thickness; Chm consists of alternating beds of sandstone and shale with well-developed ripples, and is approximately $130 \mathrm{~m}$ in thickness; Chu consists of massive sandstone with shale, and is thicker than $100 \mathrm{~m}$.

The Tsaoling landslide area is located on a large dipping monocline. The dips of strata toward the SSW are similar on both sides of the Chinshui River valley, promoting landslide occurrence on the northern side of the river valley (right bank side). At this point, the mountain flank dips steeply and in the same dip direction of rock formation. Conversely, large landslides do not occur on the left bank side because the mountain flank and the dip of the strata are in opposite directions.

The Tsaoling landslide area is located in the western limb of Tsaoling anticline which trends NNE-SSW with an eastward dipping of approximately $40^{\circ}$. To the west, the Chiuhsiungping syncline also trends NNE-SSW with eastward dips of up to $30^{\circ}-40^{\circ}$ in its western flank (Chigria et al. 2003). The Neipang Fault cuts the strata and Tsaoling anticline in the northeast of the Tsaoling area. After the 1941 Tsaoling landslide, the Chinshui Shale uniformly outcropped and dipped approximately $10^{\circ}$ with a $\mathrm{N} 70^{\circ} \mathrm{W}$ strike in the Tsaoling landslide area. The monocline area where the landslide developed is approximately $3 \mathrm{~km}$ wide, stretching from west to east between the Chiuhsiungping syncline and Tsaoling anticline. Because of this structural pattern at Tsaoling, the relatively constant shallow strata dip toward Chingshui River combined with the steeper, south-facing mountain slope facilitates landslides.
The landslide geology in of Tsaoling

Many researchers have performed rock mechanic tests in Tsaoling, including petrographic analysis, mineralogical composition analysis, general physical property examination (including dry and wet density, water content ratio, specific gravity, Atterberg limits, and grain structure analysis), slaking and durability test, and direct shear test.

To investigate the movement mechanism of slip in Tsaoling induced by the Chi-Chi Earthquake in 1999, Lee (2001) tested rocks from the Chinshui Shale and the Chaolan Formation of the Tsaoling region. The peak strength of the Chaolan Formation, obtained through a direct shear test, is $c_{\mathrm{p}}=96 \mathrm{kPa}, \Phi_{\mathrm{p}}=38.5^{\circ}$, and the residual strength is $c_{\mathrm{r}}=212 \mathrm{kPa}, \Phi_{\mathrm{r}}=19.9^{\circ}$. The normal $\left(k_{\mathrm{n}}\right)$ and shear stiffness $\left(k_{\mathrm{s}}\right)$ are 19.8 and $0.67 \mathrm{GPa} / \mathrm{m}$, respectively. The peak strength of the Chinshui Shale is $c_{\mathrm{p}}=1,388 \mathrm{kPa}, \Phi_{\mathrm{p}}=14.4^{\circ}$, and the residual strength is $c_{\mathrm{r}}=779 \mathrm{kPa}, \Phi_{\mathrm{r}}=13.4^{\circ}$. The $k_{\mathrm{n}}$ is $33.59 \mathrm{GPa} / \mathrm{m}$, and $k_{\mathrm{s}}$ is $0.676 \mathrm{GPa} / \mathrm{m}$ (Table 2).

To investigate the mechanical properties of rocks nearby Chelungpu Fault, Chen (2005) conducted a tri-axial test for the sandstone of the Chaolan Formation near Tsaoling, and determined that the single pressure strengths in dry and wet states were 37.31 and $14.03 \mathrm{MPa}$, respectively. The dry specimen's Young's modulus $\left(E_{\mathrm{dry}}\right)$ was $3.58 \mathrm{GPa}$, and the Brazilian tensile test was $2.71 \mathrm{MPa}$ (Table 2).

The role of groundwater

Five boreholes were drilled in the Tsaoling area after the 1979 Tsaoling landslide (Lee et al. 1993; Hung et al. 2002). Three holes (BH1, BH2, and $\mathrm{BH} 3)$ were drilled in the landslide area, and the other 2 (BH4 and BH5) were not drilled in the landslide area. The drill depths of the first three boreholes were $60 \mathrm{~m}$ (BH1 and $\mathrm{BH} 2$ ), and $120 \mathrm{~m}$ (BH3), with respective elevations of 780,625 , and $1,048 \mathrm{~m}$. The groundwater boreholes $\mathrm{BH} 1$ and $\mathrm{BH} 2$ were drilled into the Chingshui Shale, and the water table was found at depths of 51 and $42 \mathrm{~m}$, respectively. In borehole BH3, located near the peak of Tsaoling Mountain and drilled $120 \mathrm{~m}$ into the Chaolan Formation (i.e., to an elevation of $928 \mathrm{~m}$ ), no groundwater was encountered Table 3.
Table 2 Rock physical properties of Tsaoling

${ }^{a}$ Chen (2005)

\begin{tabular}{lcclllll}
\hline & $C_{\mathrm{p}}(\mathrm{kPa})$ & $\Phi_{\mathrm{p}}\left({ }^{\circ}\right)$ & $C_{\mathrm{r}}(\mathrm{kPa})$ & $\Phi_{\mathrm{r}}\left({ }^{\circ}\right)$ & $E(\mathrm{GPa})$ & UCS $(\mathrm{MPa})$ & \\
\hline Chaolan formation & 96 & 38.5 & 213 & 19.9 & $3.58^{\mathrm{a}}$ & $37.31(\mathrm{D})^{\mathrm{a}}$ & Lee (2001) \\
& & & & & & $14.03(\mathrm{w})^{\mathrm{a}}$ & \\
Chinshui Shale & 1,389 & 14.4 & 779 & 13.4 & & & Lee (2001) \\
\hline
\end{tabular}


Table 3 The $M>6.0$ historical earthquakes occurred near study area

\begin{tabular}{llllll}
\hline Earthquake & ML & Date & Longitude & Latitude & $\begin{array}{l}\text { Distance } \\
\text { To Tsaoling }(\mathrm{km})\end{array}$ \\
\hline Chi-Chi earthquake & 7.3 & $1999 / 09 / 21$ & 120.82 & 23.85 & 33.6 \\
After shock of Chi-Chi earthquake & 6.6 & $1999 / 09 / 21$ & 120.86 & 23.80 & 31.1 \\
Chiayi earthquake & 7.1 & $1941 / 12 / 17$ & 120.50 & 23.40 & 27.5 \\
Ruali earthquake & 6.2 & $1998 / 07 / 17$ & 120.66 & 23.52 & 6.5 \\
\hline
\end{tabular}

Lee et al. (1993) proposed a water level profile for the groundwater table based on these borehole data. All the gullies in the area exhibited abundant water flow, even during the dry season. This implies that the gullies are located below the groundwater table. According to field work after the Chi-Chi Earthquake, all of the strata lying on top of the Chinshui Shale are parallel and uniform. This suggests that groundwater was a significant factor in the 1941 and 1942 landslide block.

\section{Newmark method analysis and distinct element modeling}

This study uses the Newmark displacement method and 2D DEM based on the granular material to investigate the cause of the Tsaoling landslide in the 1941 Chiayi Earthquake. The following subsections present the principal features of this methodological approach.

Newmark displacement method

In 1965, Professor N. M. Newmark (1965) proposed the basic elements of a procedure for evaluating the potential deformations of an embankment dam caused by earthquake shaking (Seed 1979). Newmark's displacement method, which is now widely used in the earthquake engineering community, represents a popular compromise between the previous approaches. This method evaluates the ultimate displacement by computing the ground motion acceleration at which the inertia force becomes high enough to cause yielding, and by integrating the acceleration that exceeds the yield acceleration on the slide mass. Huang et al. (2001) used Newmark's displacement method to calculate the free body motion of Jih-Feng-Erh-Shan landslide blocks during the Chi-Chi Earthquake, showing that the block slid when the peak acceleration exceeded the yield acceleration. The freebody diagram in Fig. 3 (ESM only) shows the situation of the rock slide block before the earthquake. The force normal to slope is $m g \cos \delta$, where $m$ is the mass of the free-body, $\mathrm{g}$ is the gravitational acceleration, and $\delta$ is the dip angle.

A basal friction force $\mu_{s} m g \cos \delta$ balances the $m g \sin \delta$ down slope force generated by gravity and for stability of slope: $\operatorname{mg} \sin \delta<\mu_{\mathrm{s}} \mathrm{mg} \cos \delta+c A$

where $\mu_{\mathrm{s}}$ is the coefficient of static friction, $c$ is the cohesive strength across the sliding force, and $A$ is the area of the sliding surface. This study adopts a cohesion of the intact shale of $1.44 \times 10^{4} \mathrm{~N} / \mathrm{m}^{2}$ (Wieczorek et al. 1982), a density of $2.65 \mathrm{~g} / \mathrm{cm}^{3}$, dip $\delta=12^{\circ}$, and internal friction angle of $\mu_{\mathrm{s}}=18.9^{\circ}(0.34)$. The factor of safety $(F)$ for evaluating the sliding across an existing bedding plane can be defined as follows (Newmark 1965; Wilson and Keefer 1983):

$F=\left(\mu_{\mathrm{s}} \mathrm{mg} \cos \delta+c A\right) /(\mathrm{mg} \sin \delta)$.

In the Tsaoling landslide, $F$ was larger than 1 in the static state, suggesting the potential of sliding across an existing bedding plane.

Chen et al. (2003) indicated that vertical ground motion could have significant effects on the stability analysis of the Tsaoling landslide induced by the Chi-Chi Earthquake. Ingles et al. (2006) emphasized the effects of vertical ground shaking on earthquake-induced landslide evaluation. Thus, this study adopts three components of ground shaking, converted to normal and down-slip acceleration. However, there are no earthquake records from the Tsaoling area for the 1941 Chiayi Earthquake. This study assumes that the intensity of ground shaking during the 1941 Chiayi Earthquake $(M=7.1)$ was between the 1999 $(M=7.3)$ Chi-Chi Earthquake and the $(M=6.6)$ aftershock (Fig. 3a), which were recorded in Tsaoling (CHY080).

This study uses the strong motion records of CHY080 (Lee et al. 2001), recorded near the Tsaoling landslide area (Fig. 3b), to calculate the down-dip sliding acceleration as follows (Huang et al. 2001):

$S=\left(\mathrm{g} \sin \delta+a_{\mathrm{d}}\right)-\mu_{\mathrm{s}}\left(\mathrm{g} \cos \delta-a_{\mathrm{n}}\right)-c A / m$.

where $a_{\mathrm{d}}$ and $a_{\mathrm{n}}$ represent the down-dip acceleration and surface-normal acceleration components, respectively.

This study assumes that the Newmark displacement on the sliding plane during the $1941 \mathrm{Chi}-Y$ i Earthquake was between the 1999 Chi-Chi $\left(M_{\mathrm{w}}=7.6\right)$ and the aftershock of the Chi-Chi Earthquake $\left(M_{\mathrm{w}}=6.6\right)$. Calculating the second derivative of the peaks indicates that the 

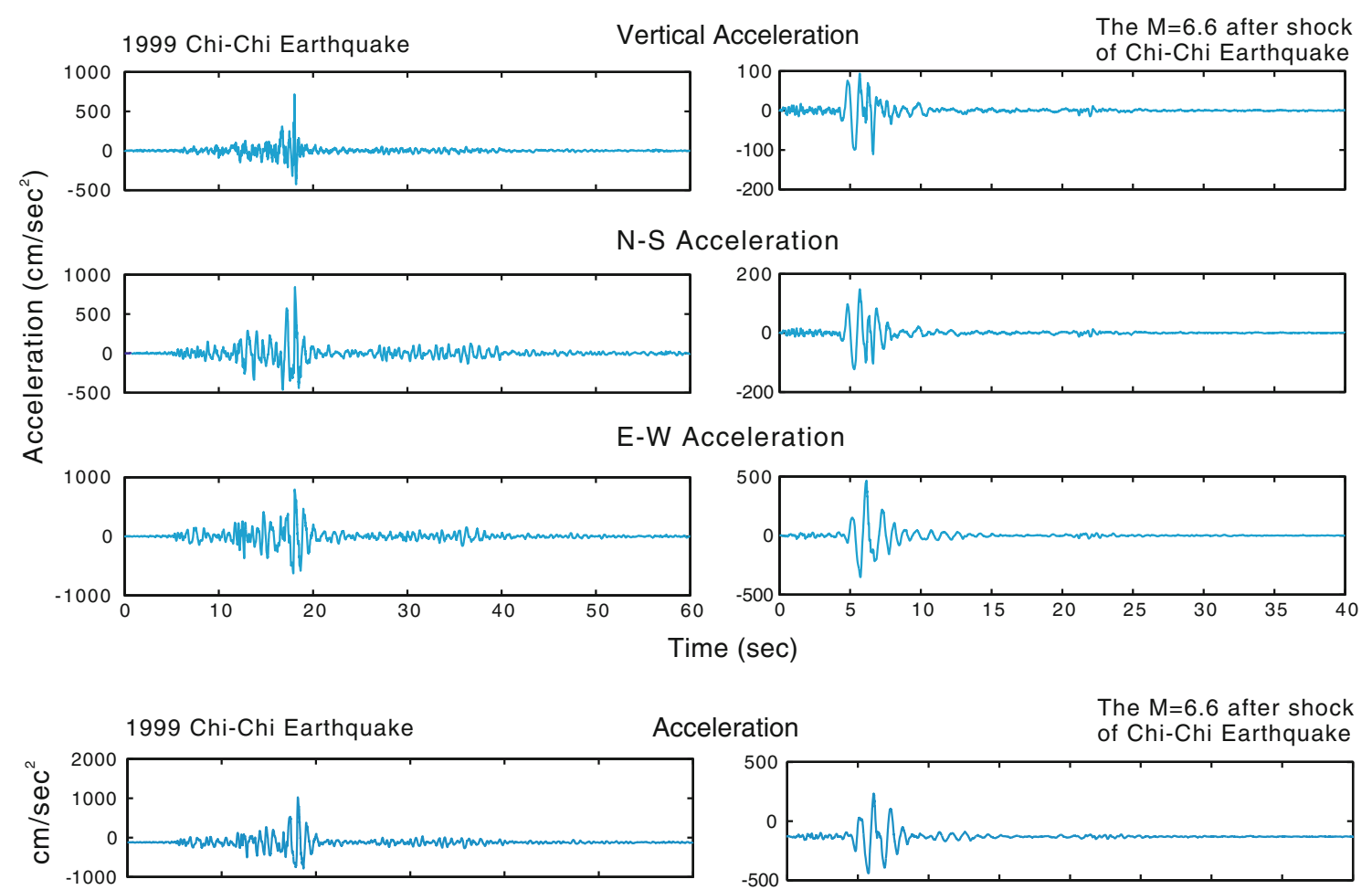

The $M=6.6$ after shock of Chi-Chi Earthquake

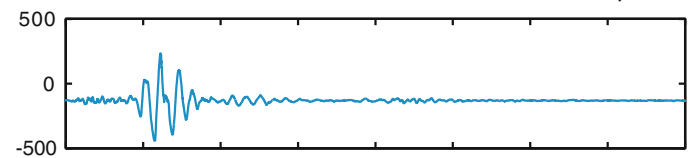

Velocity
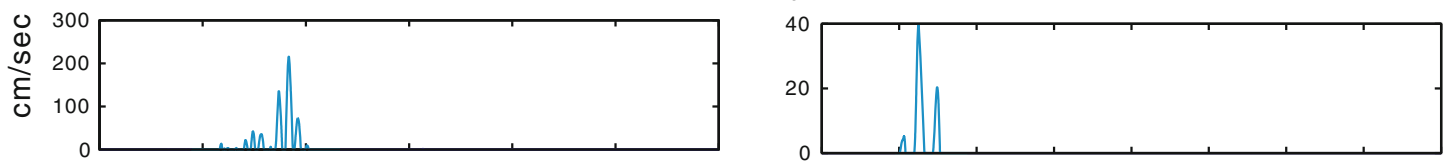

Displacement
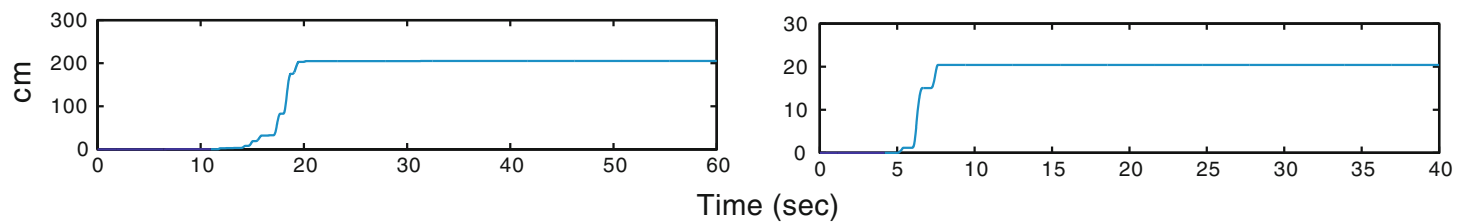

Fig. 3 a Acceleration diagram of the strong motion station during the Chi-Chi Earthquake and $M=6.6$ aftershock. b Use of the Newmark displacement method to analyze the acceleration of station CHY080 during the Chi-Chi Earthquake and $M=6.6$ aftershock. The velocities and ultimate displacements of the slide mass were

total sliding between the block and sliding surface was approximately $200 \mathrm{~cm}$ for the Chi-Chi Earthquake and $20 \mathrm{~cm}$ for the $M=6.6$ aftershock (Fig. 3b). However, pore water pressures did not change significantly during the earthquake motion or shear displacement, indicating the presence of a free and rigid body on the Tsaoling landslide slope. The critical displacement for brittle behavior is lower than that of ductile deformation, with values of $5 \mathrm{~cm}$ for the brittle mass (Wieczorek et al. 1985 ) and $10 \mathrm{~cm}$ for the ductile mass (Jibson and Keefer 1993). evaluated by integrating the effective acceleration on the sliding mass that exceeded the yield acceleration as a function of time. The ultimate displacements of the Chi-Chi Earthquake and the $M=6.6$ aftershock were 200 and $20 \mathrm{~cm}$, respectively

Distinct element modeling and granular material simulation

This study uses discrete granular simulations to investigate the mechanics of the Tsaoling landslide. The numerical model used to reproduce the described experiments represents a specific application of the Particle Flow Code in 2D (PFC2D) (Itasca 2002), which analysts frequently use to model the granular assemblies of purely frictional or bonded circular particles represented by discs. The original version of the DEM was devoted to model rock-block 
systems (Cundall 1971) and it was later used to model granular materials (Cundall and Strack 1979). Researchers generally use PFC models to determine slope stability (Wang et al. 2003), fault plane motion (Strayer and Suppe 2002; Imber et al. 2004, Strayer et al. 2004), and soil and rock mechanisms (McDowell and Harireche 2002; Cheng et al. 2003; Harireche and McDowell 2003; Potyondy and Cundall 2004). In the DEM, the global behavior of an assembly of particles connected to a network of contacts can be obtained by writing the equation of motion each component.

The parallel bond model uses a set of elastic springs at the bond periphery between two contact particles (Fig. 5a, ESM only). The finite-size cementation material is deposited between 2 particles. The shape of the parallel bond is a cylinder in a 3D model and 2D ball mode. In the 2D disk mode, the parallel bond is cuboidal shape. The contact bond can only transmit force, but the parallel bond can transmit force and momentum. When the tensile or shear stress exceeds the parallel bond strength, the parallel bond breaks. This study adopts a 2D disk mode with $1 \mathrm{~m}$ thickness for the Tsaoling landslide model.

The influence of the numerical damping parameter must be analyzed to verify the reliability of its application. Local damping can dissipate energy by effectively damping the equation of motion. Viscous damping adds normal and shear dashpots at each contact (Fig. 5b, ESM only). Viscous damping uses a spring-dashpot system. The relationship between the restitution coefficient and the damping ratio delivered by Giani (1992) can be shown as:

$\beta=\frac{|\ln D|}{\sqrt{\pi^{2}+(\ln D)^{2}}}$

where $\beta$ is the damping ratio and $D$ is the restitution coefficient.

The preliminary sensitivity analysis in this study consisted of a series of numerical simulations with viscous damping and local damping at 0.7 and 0 , respectively.

\section{Biaxial test}

In the PFC model, there is no unique way to pack a number of particles within a given volume to obtain the macroparameters, such as strength, the Poisson ratio, and Young's modulus. The initial stress state cannot be specified independently of the initial packing because the relative positions of particles determine the contact forces. Finally, setting the boundary conditions in the DEM is more complex than for continuum modeling because the boundary does not include planar surfaces. This makes it difficult to match the behavior of a simulated solid (assemblage of bonded particles) with a real solid tested in a laboratory.
Potyondy and Cundall (2004) proposed that the grain contact moduli and cement stiffness moduli are related to the corresponding normal stiffness of the assembly particles in the model, and the strength of the model determined by the parallel-bond strength and parallel-bond radius. Thus the macroproperties used in numerical experiment need to be tested by numerical biaxial tests and the further calibration of mechanical parameters. Consequently, Fakhimi and Villegas (2007) proposed the calibration of the DEM and accurately simulated the peak and residual failure envelopes and their curvatures. Yoon (2007) introduced a new method of obtaining a set of microproperties for contact-bonded particle models. This method includes design of experiment (DOE) methods and optimization techniques. However, the physical properties must fall within the following range: unconfined compressive strength (UCS) of 40-170 MPa, Young's modulus of 20-50 GPa, and a Poisson ratio of 0.19-0.25. The UCS and Young's modulus of the Chaolan Formation are $37.3 \mathrm{MPa}$ and $3.58 \mathrm{GPa}$ (Chen 2005), respectively. Thus, this new method is unsuitable for modeling the Chaolan Formation in Tsaoling. Therefore, this study includes a series of biaxial numerical tests on the granular samples to derive the macroproperties (UCS and Young's modulus) of the Chaolan Formation (Fig. 6, ESM only). This study also identifies the microproperties of the ball-ball contact modulus, parallel bond modulus, and parallel bond strength.

\section{Stability of numerical experiments for the Tsaoling landslide}

Based on field investigation, the Tsaoling model in this study measured 3,800 $\mathrm{m}$ in length and $1,208 \mathrm{~m}$ in height (Fig. 4a). The simulation sets the ground shaking on the boundary (wall element). The shear displacement, shear velocity, and stress in the landslide block were monitored. The 25 s ground shaking amplified from the 1998 Reuli Earthquake recorded by CHY080 (Tsaoling strong motion station). The maximum horizontal and vertical accelerations were 0.75 and $0.3 \mathrm{~g}$, and the duration of ground shaking is about $5.2 \mathrm{~s}$ (Fig. 4b, c).

\section{The PFC2D model}

The numerical parameters obtained from the unconfined compressive test include a Young's modulus of $E=3.58 \mathrm{GPa}$, Poisson ratio of $v=0.19$, UCS of 37.3 $\mathrm{MPa}$ (Chen 2005), and an internal friction angle of $35.2^{\circ}$. Laboratory test showed that the macroscopic properties of the numerical sample are similar to the properties of the rock samples from the Chaolan Formation (Yeng 2000; Lee 2001) (Tables 2). 


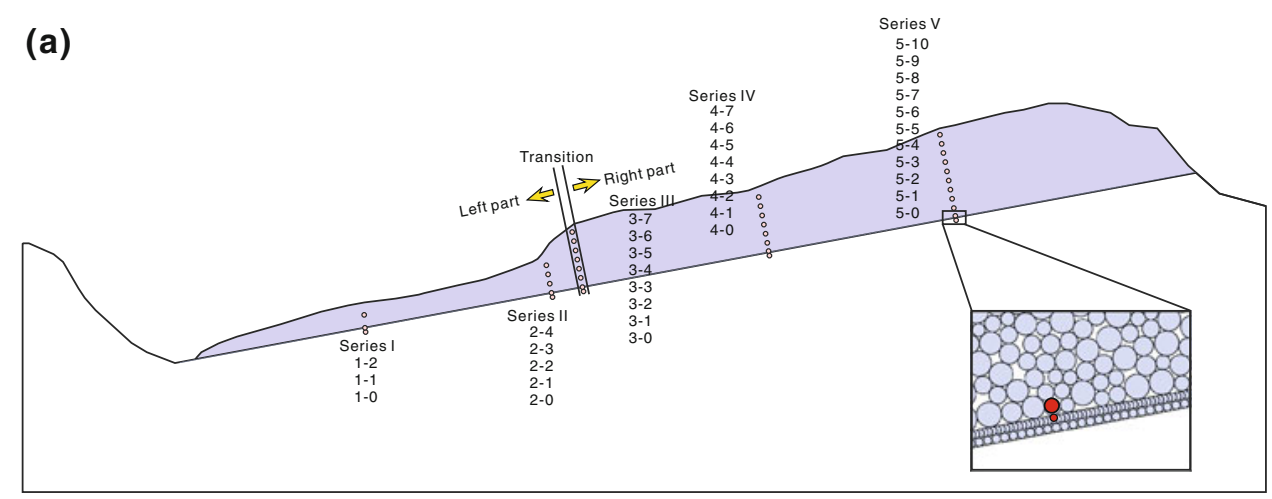

(b)

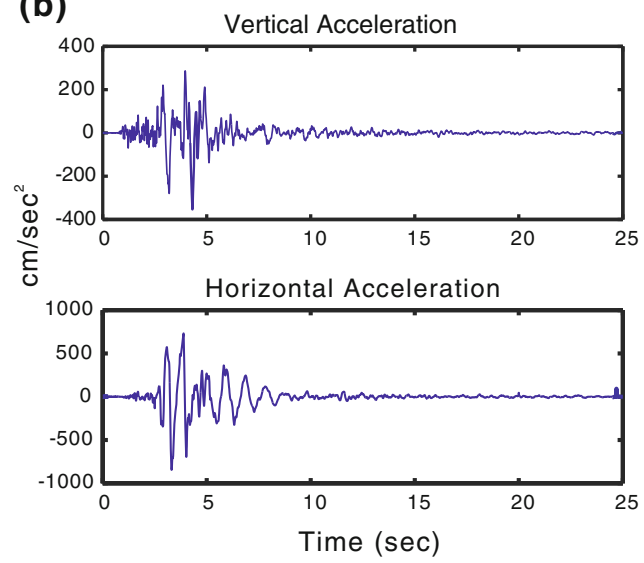

Fig. 4 a The proposed PFC model includes 34,000 discs, with 5,756 discs for the base and 28,244 discs for the block. In total, 35 monitored particles were divided into 5 series (Series I to V). All bottom monitored particles (1-0 to 5-0) were located on the shear plane, and the displacement and velocity of every monitored particle

The numerical model includes 34,000 disks, with 5,756 disks for the base and 28,244 disks for the block. The 5,756 disks put on the landslide surface (base) were half overlapped by the clump (Fig. 4a). The clump behaves as a rigid body, but contact force exists when a particle is added to the clump. The behavior of a clump differs from that of bonded particles, but it can bond with other particles. However, the behavior of the ball-wall contact of the PFC model is not cohesive, and this model adopts the ballclump contact for the landslide block and sliding surface. The block was divided into 3 parts (left, transition, and right parts) and installed 31 monitor particles (divided into 5 series) for PFC simulation (Fig. 4a). Table 4 shows the physical properties (macroproperties) of the model as derived from the particle properties (microproperties, Table 5) of the biaxial test.

Field measurements indicate that the landslide surface is flat and continuous (Fig. 8, ESM only). The strata under the sliding plane consist of thin sandstone and mud. The strength of the mud between the sandstone is weak and cohesiveless.

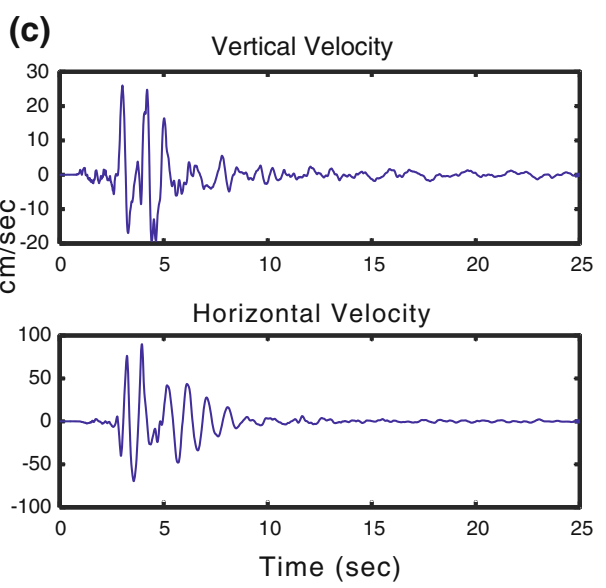

relative to the shear plane were recorded. The input vibration of numerical simulation, the vibration was amplified by the 1998 Ruali Earthquake and transferred the $\mathrm{N}-\mathrm{S}$ and $\mathrm{E}-\mathrm{W}$ components to horizontal components. $\mathbf{b}$ The acceleration histograms, $\mathbf{c}$ the velocity histograms integral from the acceleration histograms

According to the strong motion data, the vibrations at Tsaoling station (CHY080) were larger than at neighboring stations during the Chi-Chi Earthquake and $M=6.6$ aftershock on 1999/09/23. The PGA records of CHY080 were more than three times greater than those of some stations near Tsaoling (Table 6; Fig. 1a). Thus, the seismic wave was likely amplified by topographic effects (Jibson 1987).

For removing the polar effect of the seismic wave (Gazetas et al. 2009), the 1998 Ruali Earthquake recorded by ChY080 was selected. The 1998 Ruali Earthquake and 1941 Chiayi Earthquake were similar, having the same focal mechanism and the same propagation path from the epicenter to the Tsaoling landslide area (Fig. 1a). By linear regression of the three PGAs recorded at CHY080 station during 1998 Ruali Earthquake, the 1999 Chi-Chi Earthquake and one $M=6.6$ aftershock on $1999 / 09 / 23$, the inferred maximum accelerations of $0.3 \mathrm{~g}$ in the vertical component and $0.75 \mathrm{~g}$ in the horizontal component are applied for vibration simulation of 1941 event (Fig. 8, ESM only). This study simulates the effects of earthquake vibrations by integrating the acceleration histogram with 
Table 4 Rock properties and PFC model macroproperties

\begin{tabular}{lll}
\hline Item & Cholan formation & $\begin{array}{l}\text { PFC model } \\
\text { (Macroproperties) }\end{array}$ \\
\hline Density & $\begin{array}{l}2.500 \mathrm{~kg} / \mathrm{m}^{3} \\
18.9^{\circ}(0.342) \text { Lee et al. } \\
(1993)\end{array}$ & $\begin{array}{l}2,650 \mathrm{~kg} / \mathrm{m}^{3} \\
18.9^{\circ}\end{array}$ \\
$\Phi_{\mathrm{r}}$ & $\begin{array}{l}3.58 \mathrm{GPa} \text { Chen }(2005) \\
\text { Young's modulus } \\
(E)\end{array}$ & $3.60 \mathrm{GPa}$ \\
UCS & $37.3 \mathrm{MPa}$ Chen $(2005)$ & $37.5 \mathrm{MPa}$ \\
\hline
\end{tabular}

Table 5 The microproperties of PFC model

\begin{tabular}{ll}
\hline Item & PFC model (Microproperties) \\
\hline Minimum radius $\left(R_{\min }\right)$ & $1.52 \mathrm{~m}$ \\
Ball radius ratio $\left(R_{\max } / R_{\min }\right)$ & 2 \\
Ball-ball contact modulus $(E c)$ & $3.0 \mathrm{GPa}$ \\
Ball stiffness ratio $\left(k_{\mathrm{n}} / k_{\mathrm{s}}\right)$ & 2 \\
Ball friction coefficient $(\mu)$ & 0.5 \\
Parallel bond radius multiplier $(\lambda)$ & 0.8 \\
Parallel bond modulus $\left(\bar{E}_{\mathrm{c}}\right)$ & $3.0 \mathrm{GPa}$ \\
Parallel bond stiffness ratio $\left(\bar{k}_{\mathrm{n}} / \bar{k}_{\mathrm{s}}\right)$ & 2 \\
Parallel bond normal strength $\left(\bar{\sigma}_{\mathrm{c}}\right)$ & $48 \mathrm{MPa}$ \\
Parallel bond shear strength $\left(\bar{\tau}_{\mathrm{c}}\right)$ & $24 \mathrm{MPa}$ \\
\hline
\end{tabular}

Table 6 The strong motion records of near Tsaoling during 1999 Chi-Chi earthquake and $M=6.6$ aftershock

\begin{tabular}{lllll}
\hline $\begin{array}{l}\text { Station } \\
\text { number }\end{array}$ & $\begin{array}{l}\text { Distance to } \\
\text { epicenter }\end{array}$ & $\begin{array}{l}\text { Vertical of } \\
\text { PGA (g) }\end{array}$ & $\begin{array}{l}\text { N-S of } \\
\text { PGA (g) }\end{array}$ & $\begin{array}{l}\text { E-W of } \\
\text { PGA (g) }\end{array}$
\end{tabular}

\begin{tabular}{lllll}
\hline (a) The 1999 Chi-Chi earthquake records \\
CHY028 & 32.1 & 0.342 & 0.765 & 0.637 \\
CHY029 & 38.9 & 0.161 & 0.238 & 0.289 \\
CHY080 & 31.7 & 0.731 & 0.859 & 0.809 \\
CHY101 & 30.9 & 0.165 & 0.398 & 0.340 \\
CHY074 & 38.8 & 0.100 & 0.160 & 0.234 \\
(b) The records of $M=6.6$ aftershock & & \\
CHY028 & 23.69 & 0.048 & 0.141 & 0.167 \\
CHY029 & 40.27 & 0.030 & 0.071 & 0.070 \\
CHY080 & 30.18 & 0.114 & 0.220 & 0.474 \\
CHY101 & 33.31 & 0.220 & 0.122 & 0.146
\end{tabular}

Italics represent the PGA record of Tsaoling strong motion station (CHY080)

the velocity histogram and applying it to the wall boundary.

The simulation of shear displacement during earthquake

All of the particles in the model were static before simulation. The maximum background vibration of the particles was less than $5 \times 10^{-6} \mathrm{~m} / \mathrm{s}$. Figure 5 a shows the shear displacement of the block on the landslide shear surface after the vibration simulation. The shear displacements of the particles ranged from 0.2 to $1.7 \mathrm{~m}$. The shear displacement of the left part was greater than that of the right part, and the variation of the shear displacement was discontinuous. The block can be divided into 8 sections based on shear displacement distances (Fig. 5b). The shear displacement of the red portion over $1.3 \mathrm{~m}$ was considered that slid down in 1941 landslide, and the other portions remained on the slope, with displacements less than $1.3 \mathrm{~m}$.

Figure 6 shows the displacement of monitored particles on the shear surface. The block can be divided into 3 portions; right part (4-1, 5-1), transition (3-1), and left (1-1, 2-1) based on the displacements of different portions on the sliding plane. Most of the shear displacement occurred from 4 to $8 \mathrm{~s}$. The shear displacement of the monitored particles ranged from 0.5 to $1.6 \mathrm{~m}$. The monitor particle displacements of the left part (Series I, II) were all approximately 1.5 to $1.6 \mathrm{~m}$, and were larger than the right part (0.5-1.2 m, Series IV, V). The transition displacements were $1.4 \mathrm{~m}$ for the base particle (3-1), and $1.5 \mathrm{~m}$ for other particles. The historical diagrams of shear displacement suggest no vibration in the left particles. For the base particle of Series III (3-1), the shear displacement of $1.4 \mathrm{~m}$ is slightly less than that of Series I and II. For the historical shear displacement of Series IV, the monitored particles vibrated relative to the clumped basal particle. The vibration period was approximately $1.5 \mathrm{~s}$ with a $9 \mathrm{~cm}$ amplitude, but the shear displacements were less than that of Series III, ranging from 0.95 to $1.2 \mathrm{~m}$. For the historical displacement of Series V, the vibration amplitude exceeded that of Series IV, and the vibration period was approximately $1.7 \mathrm{~s}$ with a maximum amplitude of $30 \mathrm{~cm}$. The shear displacement ranged from 0.5 to $0.6 \mathrm{~m}$, less than that of Series IV. These vibrations imply that the particles in the block collide and dissipate earthquake energy. The particles near to the ground surface (ex. particle 5-5 near than 5-4, Fig. 6, ESM only) in the same series of monitored particles relative to the sliding surface demonstrate the larger down-dip displacement (Fig. 6). This phenomenon indicates that the particles in the right part push down the particles in the lower part during earthquake vibration.

The shear velocity of the block during earthquake simulation

The monitoring particles were also used to estimate the shear velocity of the block on the shear plane. Almost all of the shear velocity occurred from 3 to $8 \mathrm{~s}$, corresponding to the seismic wave vibration (Fig. 3) and particle displacement (Fig. 6). The extremely high shear velocity of $3.4 \mathrm{~m} / \mathrm{s}$ for Particle 3-1 occurred at approximately $3.3 \mathrm{~s}$, and the maximum velocity down-dip and up-slope velocity of the 
Fig. 5 The particle displacements after numerical simulation. a The displacement ranges from 0.2 to $1.8 \mathrm{~m}$. b The variations in displacement are not continuous, but discrete
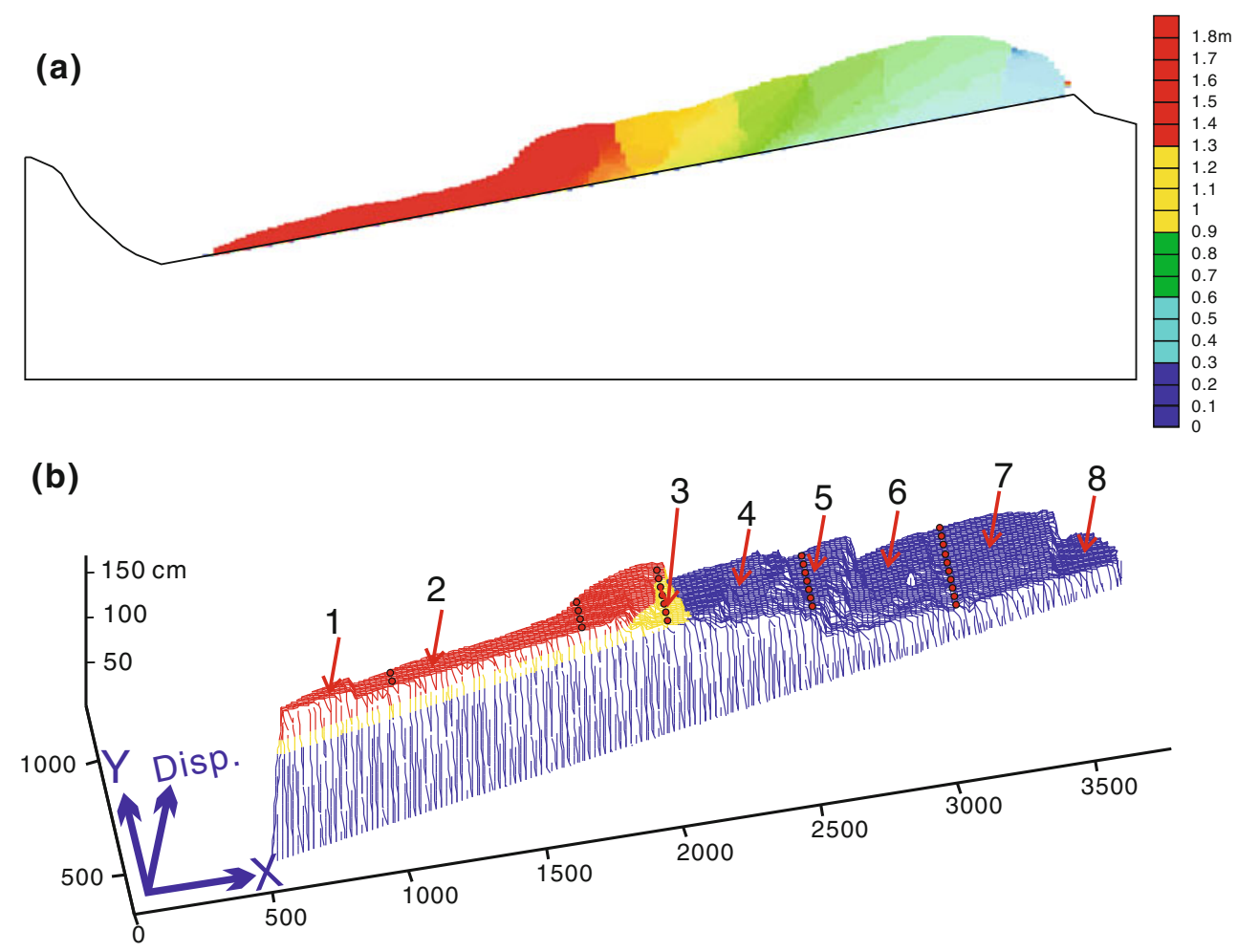

other particles were close to $1 \mathrm{~m} / \mathrm{s}$. The maximum upslope and down velocity of Particle 3-1 was 1.7 and $3.4 \mathrm{~m} / \mathrm{s}$ at approximately $3.4 \mathrm{~s}$ (Fig. 11, ESM only). This suggests that the stresses quickly concentrate at the transition zone. Monitoring the stress of Particle 3-1 shows that the stresses oscillated significantly from 3.0 to $3.4 \mathrm{~s}$. The transition zone with a high shear velocity and displacement correlated with the 1941 landslide detachment scarp.

The crack development in the block

In addition to monitoring particle displacement, this study records the development of cracks in the block. Figure 7 shows the historical variations of crack development. The cracks developed from the bottom (near the shear surface) up to the top in the block (near the ground surface). The cracks in the bottom (near the shear surface) were more intensive than the upper part (near the ground surface).

Crack development began from the bottom portion of the block at $3.2 \mathrm{~s}$, and then increased fast during the high vibration period (Figs. 7 and 8). After $5 \mathrm{~s}$, the crack developed slowly. The crack distribution was concentrated in certain zones, which correspond to the high gradient variation of the shear displacement of the block (Figs. 7 and 5b). A comparison of the shear displacement and crack distribution shows that the width of the tensile crack in the block of concentrate crack zones is $10-30 \mathrm{~cm}$. The concentrated crack zones correlated with subsequent landslidedetached surfaces (i.e., the 1942 and 1999 events). The
3,046 cracks were divided into four zones. Zone III, which matches the 1942 landslide event, contains the most cracks (1,374). Zone II, with 779 cracks, fits the 1941 event. Zone I belongs to the 1941 landslide block, and contains relatively few cracks (262). Zone IV contains two obvious fractures, one of which fits the 1999 landslide induced by the Chi-Chi Earthquake. The other fracture could represent a scarp for a future event. The distribution of the shear crack (yellow) is near the shear plane, and most of the cracks near the surface (upper) are tensile (Fig. 7).

The stress during the earthquake simulation

Figure 13 (ESM only) shows the stress variations of the monitored particles on the shear plane (1-1, 2-1, 3-1, 4-1, and 5-1). Positive values represent extension, and negative values represent compression. Before earthquake simulation, the horizontal normal compressional stress of monitored particles in the right part exceeded that in the left part. However, after $10 \mathrm{~s}$ of vibration simulation, the normal compressional stress of Particle 4-1 exceeded that of Particle 5-1 and remained stable. Particle 3-1, which was located at the transition zone, had an extensional stress peak of approximately 6.5 MPa at 2.9 s, and Particle 5-1 had a compressional stress peak of approximately $7.8 \mathrm{MPa}$ at $3.6 \mathrm{~s}$. Almost all of the shear displacement occurred from 3.0 to $4.3 \mathrm{~s}$, and the largest vibration of the seismic wave occurred in this period (Fig. 6). All of the shear stresses of the particles exhibited harmonious oscillation after $4.5 \mathrm{~s}$. 

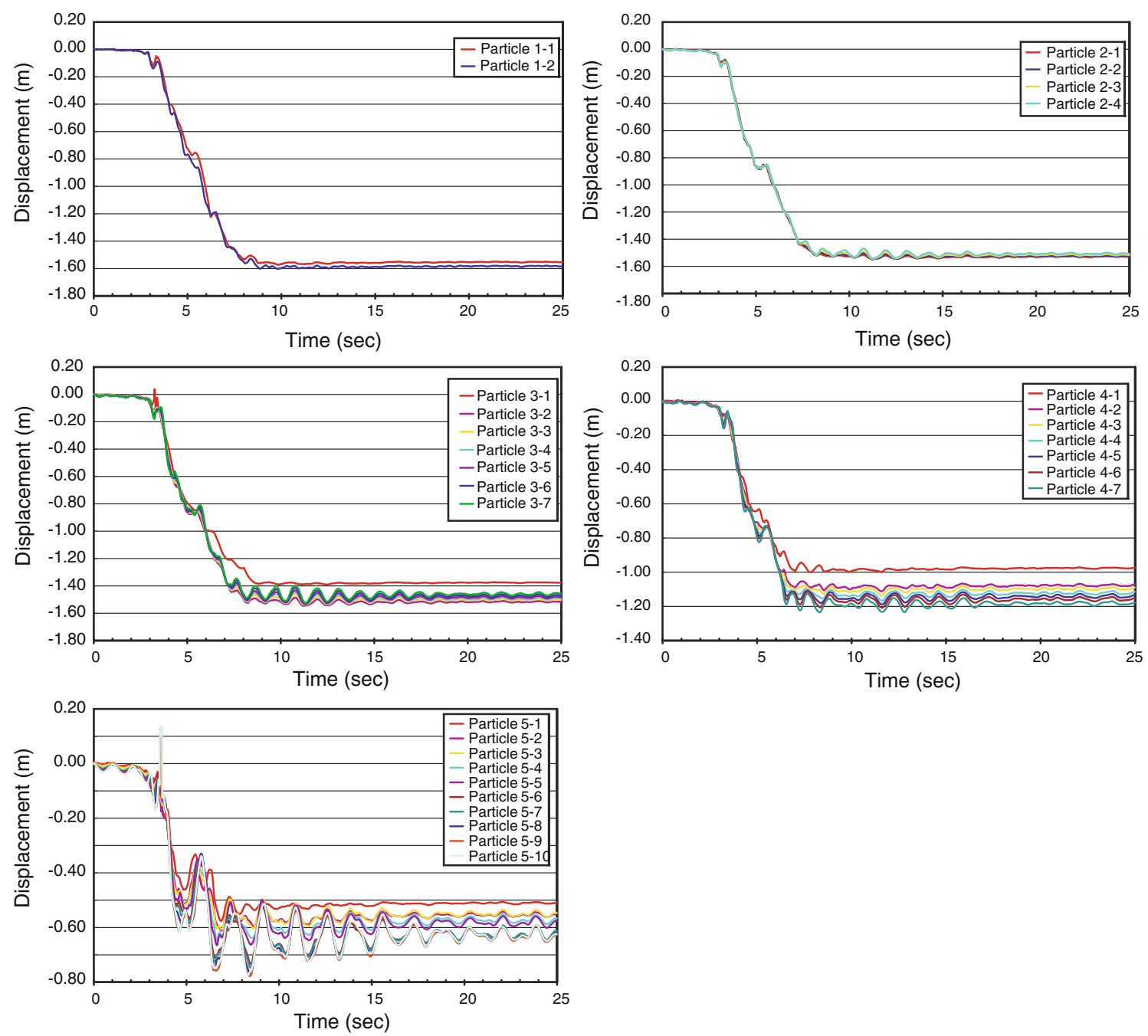

Fig. 6 The histogram of monitored particle displacement. The behavior of Series I and II suggest a rigid body during vibration. For Series III to V, the displacement of upper particles (near the

\section{Discussion}

The 1941 Tsaoling landslide simulated by Distinct Element Model bring important physical constrains for particle collision during the landslide, the crack development as well as the critical landslide displacement and velocity. The following three subsections present the important constraints and results of the 1941 Tsaoling landslide simulated by distinct element numerical simulation. These sections also address particle collision, crack development, and the critical landslide threshold. These modeling results provide a few additional results that provide new insights into earthquake-triggered landslides, such as stress variation and displacement during earthquake shaking. ground surface) is greater than that of lower particles (near the shear surface). The amplitude of vibration is also greater in upper particles than lower particles

Particle collision

Inconsistency in particle displacement implied the tension of the block during seismic wave simulation. This phenomenon could occur after particle collision in the block. We divided the block into right and left portions, and applied the same seismic wave to each portion. The displacement of the right part of the block increased from 0.7 to $0.83 \mathrm{~m}$, and the left part of the block decreased from 1.55 to $1.13 \mathrm{~m}$ (Fig. 14, ESM only). This change in shear displacement and stress oscillation implies that the particles in the right part of the block pushed down the particles in the left part during the earthquake simulation. After collision, the rebound forces exceeded the strength of the interparticle parallel bonds, generating cracks in the block at stress-concentrated zones. 

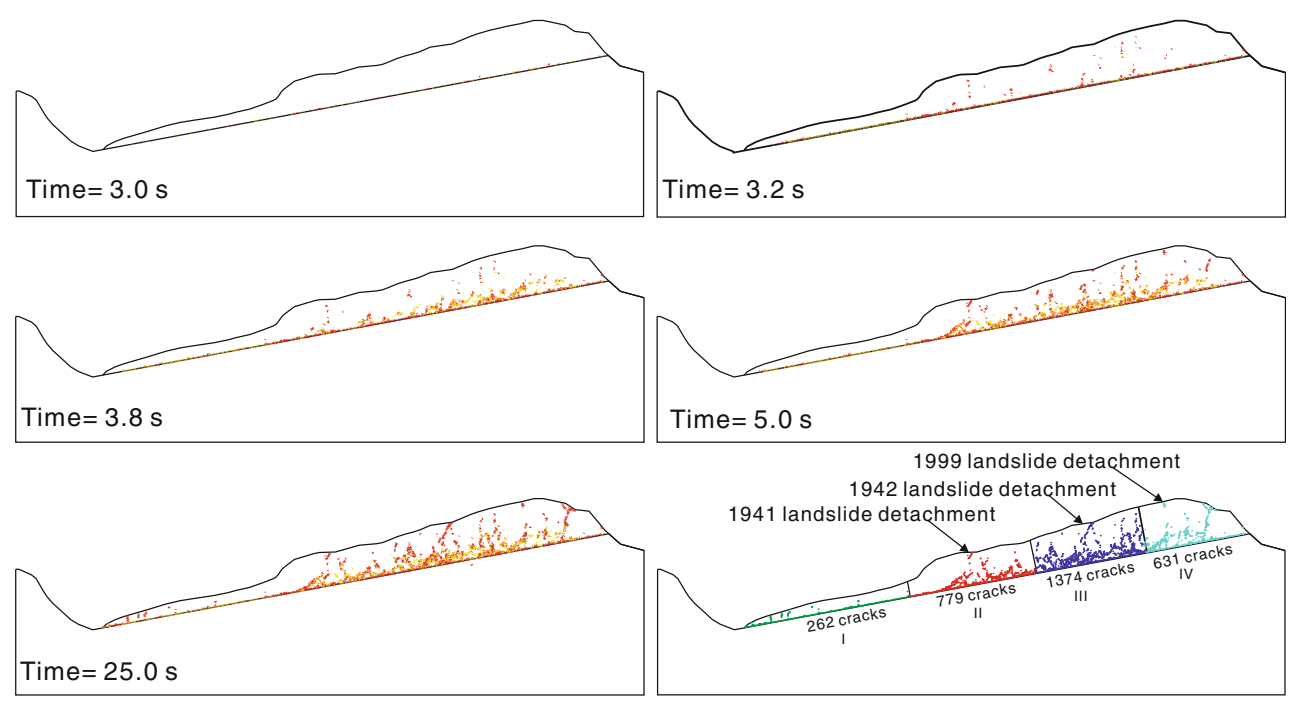

Fig. 7 The crack development over time. After $3.0 \mathrm{~s}$, the crack only occurred on the shear surface. The cracks develop from 3.2 to $5.0 \mathrm{~s}$, and slows at $25 \mathrm{~s}$. The cracks concentrate in specific zones. The red and yellow short segments represent tension and shear cracks, respectively

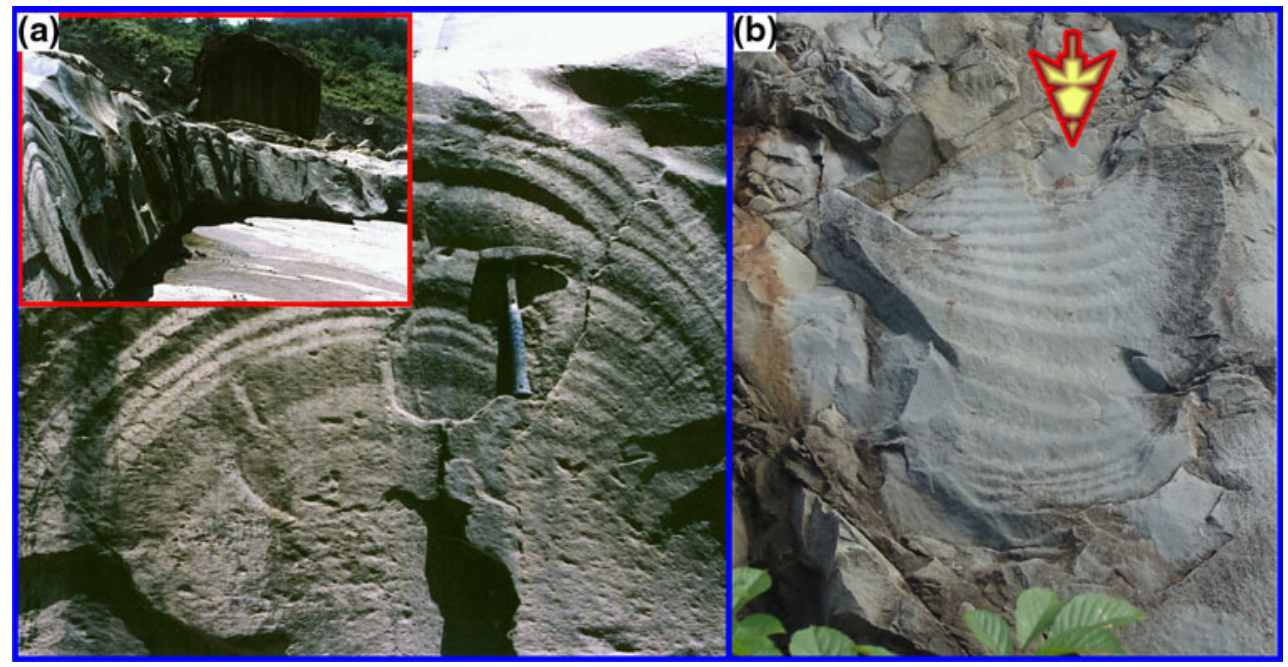

Fig. 8 Outcrops of Tawo Sandstone with ring-shaped rib marks found in the Chinshui River valley before the Chi-Chi earthquake: a A rib mark outcrop on the Chinshui River bed. b A rib mark outcrop on a roadside exposed by an excavator

\section{Crack development}

Tang et al. (2009) proposed a quasi-rigid block by simulating the survival of local resident living on the sliding block during the Tsaoling landslide triggered by the 1999 Chi-Chi Earthquake. The landslide block is neither rigid nor plastic, but is instead deformed by stress. When the stress exceeds the rock strength, the block breaks and generates cracks. The cracks near the shear surface are denser than those near the ground surface because the seismic wave propagated from the bottom of the block. The relationship between cracks and the topography of the block is unremarkable (Fig. 7).

An outcrop of Tawo Sandstone with ring-shaped rib marks was found in the Valley of Chinshui River before the
Chi-Chi Earthquake. The rib marks were arranged in a neat row and all of the ring centers were located at the bottom of the strata (Fig. 8). According to Hodgson (1961), the rib marks are circular or elliptical crack arc lines shown on surface crack, which are formed owing to change of stress state in the rupture process, the stress caused by a temporary decline to suspend the construction of the surface crack. The patterns of rib marks can be estimated by the initiation of rupture point and rupture propagation velocity. If erosion decompresses the fractures in the river bed, the cracks could propagate from the top of the strata. However, the initial crack points located at the bottom of the strata indicate that the stress propagated from the bottom. The multi-ring-shape rib marks show that this phenomenon was caused by multiple events (Jeng et al. 2002). The cracks 
and rib marks were likely formed by recurring earthquakes in Southwestern Taiwan over the last 100 years.

Critical landslide displacement and velocity

For the rock test of the Chaolan Formation in Tsaoling, the friction angle of $18.9^{\circ}(0.342)$ is larger than the slope of the Tsaoling landslide area (approximately $12^{\circ}$ ). Hence, the block should generally stop sliding after the earthquake. However, the block continued to slide after the earthquake vibration during the 1941 Chiayi Earthquake and 1999 ChiChi Earthquake. This caused a significant change in the physical properties of the shear slide surface. Han et al. (2007) suggested that high-velocity friction between rocks would produce high-temperature and exiguous grains, reducing the friction coefficient to less than 0.1 . Hirose and Bystricky (2007) performed a rock test to find a critical effect on earthquake slip instability and seismic energy release. The results of their high-velocity friction experiments on simulated faults in serpentine under earthquake slip conditions show a decrease in the friction coefficient from 0.6 to 0.15 as the slip velocity reaches to $1.1 \mathrm{~m} / \mathrm{s}$ at a normal stress of up to 24.5 MPa. Di Toro et al. (2004) showed that rubbing wet rock specimens with a friction velocity as high as $1 \mathrm{~m} / \mathrm{s}$ produced a gel material composed of a layer of non-crystalline micro-quartz grains. The PFC simulation results in this study show that the sliding velocity of the block on the shear surface is nearly $1 \mathrm{~m} / \mathrm{s}$. Thus, even a small friction coefficient could trigger a landslide. However, the right part of the block collided downward, increasing the shear displacement and velocity of the left part of the block. Hence, the shear velocity of left part of the block exceeded the threshold of the slide, triggering a landslide.

\section{Conclusion}

Based on the PFC model and seismic wave simulation, this study presents the following major results:

1. The cracks developed from the shear surface to the ground surface during earthquake vibration. The crack distribution concentrated in specific zones, which correlated to subsequent landslide detachment surfaces (i.e., the 1942 and 1999 events).

2. The different parts of the block collided with each other during vibration simulation. The right part of the block slid a short distance and then stayed on the slope, and the left part of the block was pushed down by the right part of the block. This collision pushed down a certain length to the left part of the block. The shear length was less than the strength of the sliding plane causing a landslide during the 1941 earthquake.
In the first approximation, the edges of the landslide could be considered relatively perpendicular to the transport direction. Thus, the modeling in this study could be performed in $2 \mathrm{D}$, the first involving an implicit condition of null displacement and the second involving strain perpendicular to transport.

The proposed complex 3D model in this study was built for the kinematic simulation of the Tsaoling landslides in 1999 and 1941. However, for landslide areas where these geometrical conditions cannot be satisfied, 3D modeling is compulsory.

Acknowledgments The comments and suggestions from Editor-inChief James W. LaMoreaux, Francesco Rapisarda and two anonymous reviewers are deeply appreciated. This study was supported by National Science Council (project number: 99-2116-M-002-020-).

Open Access This article is distributed under the terms of the Creative Commons Attribution License which permits any use, distribution, and reproduction in any medium, provided the original author(s) and the source are credited.

\section{References}

Angelier J, Barrier E, Chu HT (1986) Plate collision and paleostress trajectories in a fold-thrust belt: the foothill of Taiwan. Tectonophysics 125:161-178

Campbell CS, Cleary PW, Hopkins M (1995) Large-scale landslide simulations: global deformation velocities and basal friction. J Geophys Res 100:8267-8283

Chan HC, Einstein HH (1981) Approach to complete limit equilibrium analysis for rock wedge-The method of Artificial supports. Rock mech 14:59-86

Chang LS (1951) Topographic features and geology in the vicinity of the nature reservoir near Tsao-Ling: Taiwan Reconstruction Monthly 1(6): 22-27. (in Chinese)

Chang SC (1984) Tsao-Ling Landslide and its effect on a reservoir, project. In: Proceedings 4th International Symposium on Landslides, vol 1 Canadian Geotech Soc, Toronto. pp 469-473

Chen CW (2005) Primary study of the rock mechanics around the Chelungpu-fault. Master Thesis, Department of Civil Engineering, National Taiwan University, Taipei

Chen TC, Lin ML, Hu JJ (2003) Pseudo-static analysis of Tsaoling rockslide caused by Chi-Chi earthquake. Eng Geol 71:31-47

Chen RF, Chan YC, Angelier J, Hu J-C, Huang C, Chang KJ, Shih TY (2005) Large earthquake-triggered landslides and mountain belt erosion: the Tsaoling case Taiwan. C R Geosci 337:1164-1172

Cheng YP, Nakata Y, Bolton MD (2003) Discrete element simulation of crushable soil. Géotechnique 53(7):633-641

Chigira M, Wang WN, Furuya T, Kamai T (2003) Geological causes and geomorphological precursors of the Tsaoling landslide triggered by the 1999 Chi-Chi earthquake, Taiwan. Eng Geol 68:259-273

Cho N, Martin CD, Sego DC (2007) A clumped particle model for rock. Int J Rock Mech Min Sci 44:997-1010

Cundall PA (1971) A computer model for simulating progressive large scale movement in blocky rock systems. In: Proceedings of the Symposium of the International society of rock mechanics. Nancy France 1, II-8 
Cundall PA (1988) Formulation of a three dimensional distinct element model-Part I. A scheme to detect and represent contacts in a system composed of many polyhedral blocks. Int J Rock Mech Min Sci 25(3):107-116

Cundall PA and Hart RD (1985) Development of generalize 2-D and 3-D distinct element programs for modeling jointed rocks. Misc. Paper SL-85_1. U.S. Army Corps of Engineers, Itasca Consulting Group

Cundall PA, Strack PDL (1979) A discrete numerical model for granular assemblies. Géotechnique 29:47-65

Di Toro G, Goldsby DL, Tullis TE (2004) Friction falls towards zero in quartz rock as slip velocity approaches seismic rates. Nature 427:436-439

Fakhimi A, Villegas T (2007) Application of dimensional analysis in calibration of a discrete element model for rock deformation and fracture. Rock Mech Rock Eng 40:193-211

Gazetas MASCEG, Garini E, Anastasopoulos I, Georgarakos T (2009) Effects of near-fault ground shaking on sliding systems. J Geotech Geoenviron Eng 135:1906-1921

Giani GP (1992) Rock slope stability analysis. A. A. Balkema, Rotterdam, p 361

Goodman RE, Brey JW (1976) Topping of rock slopes, in rock engineering for foundation and slopes. In: Special Conference A.S.C.E., vol 2, Boulder, pp 201-234

Han R, Shimamoto T, Hirose T, Ree JH, Ando JI (2007) Ultralow friction of carbonate faults cause by thermal Decomposition. Science 316:878-881

Harireche O, McDowell GR (2003) Discrete element modelling of cyclic loading of crushable aggregates. Gran mat 5:147-151

Hart R, Cundall PA, Lemos L (1988) Formulation of a threedimensional distinct element model-Part II. Mechanical calculation for motion and interaction of a system composed of many polyhedral blocks. Int J Rock Mech Min Sci 25(3):117-125

Hirose T, Bystricky M (2007) Extreme dynamic weakening of faults during dehydration by coseiemic shear heating. Geophys Res Lett 34:L14311. doi:10.1029/2007GL030049

Hodgson SA (1961) Classification of structures on joint surfaces. Am J Sci 259:493-502

Hsu ST (1951) The Tsao-Ling dammed up lane. Natl Taiwan Univ Civil Eng 1:3-4

Hsu TL, Leung HP (1977) Mass movements in the Tsaoling area, Yunlin-Hsien, Taiwan. Proc Geol Soc China 20:114-118

Huang CS, Ho HC, Liu HC (1983) The geology and landslide of Tsaoling area, Yunlin, Taiwan. Bull Central Geol Sur 2:95-112

Huang CC, Lee YH, Liu HP, Keefer DK, Jibson RW (2001) Influence of surface-normal ground acceleration on the initiation of the Jih-Feng-Erh-Shan landslide during the 1999 Chi-Chi, Taiwan, Earthquake. Bull Seis Soc Am 91:953-958

Hung JJ (1980) A study of Tsaoling rockslides, Taiwan. J Eng Env (in Chinese) 1:29-30

Hung JJ, Lee CT, Lin ML (2002) Tsao-Ling rockslides, Taiwan. Geo Soc Am Rev Eng Geol XV:91-115

Imber J, Tuckwell GW, Childs C, Walsh JJ, Manzocchi T, Heath AE, Bonson CG, Strand J (2004) Three-dimensional distinct element modelling of relay growth and breaching alone normal faults. J Stru Geol 26:1897-1911

Ingles J, Darrozes J, Soula JC (2006) Effects of the vertical component of ground shaking on earthquake-induced landslide displacements using generalized Newmark analysis. Eng Geol 86:134-147

Itasca, Consulting Group Inc. (2002) PFC2D particle flow code in 2 dimensions. User's Guide. Minneapolis

Jeng FS, Lin ML, Lin HC (2002) Study on the fracturgraphy and failure mechanism of brittle materials. Bull Coll Eng 85:49-57

Jibson R (1987) Summary of research on the effects of topographic amplification of earthquake shaking on slope stability. Open-File Report 87-268, U. S. Geological Survey, Menlo Park
Jibson RW, Keefer DK (1993) Analysis of the seismic origin of landslides-examples of the New Madrid seismic zone. Geol Soc Am Bull 105:521-536

Kawada S (1942) Untersuching des neuen Sees gebildet infolge des Erdbebens vom Jahre 1941 in Taiwan (Formosa). Bull Earthq. Res Inst Univ (in Japanese) Tokyo 21:317-325

Lee CN (2001) Preliminary study on the Tsao-Ling landslide area under earthquake. Master Thesis, Department of Civil Engineering, National Taiwan University, Taipei

Lee CT, Hung JJ, Lin ML, Tsai LY (1993) Engineering geology investigations and stability assessments on Tsao-Ling landslide area: a special report prepared for Sinotech Engineering Consultants. p 224 (in Chinese)

Lee WHK, Shin TC, Wu CF (2001) Free-field strong motion data from the 9-21-1999 Chi-Chi Earthquake. Strong-Motion Data Series CD, Central Weather Bureau

Lin D, Fairhurst C (1988) Static analysis of the stability of threedimensional rock block systems using topological techniques. Int J Rock Mech Min Sci 24(6):331-338

McDowell GR, Harireche O (2002) Discrete element modeling of soil particle fracture. Géotechnique 52:131-135

Mouthereau F, Deffontaines B, Lacombe O, Angelier J (2002) Variations along the strike of the Taiwan thrust belt: basement control on structural style, wedge geometry, and kinematics. Geol Soc Am Special Paper 358:35-58

Newmark NM (1965) Effects of earthquake on dams and embankments. Géotechnique 15:139-160

Potyondy DO, Cundall PA (2004) A bonded-particle model for rock. Int J Rock Mech Min Sci 41:1239-1364

Seed HB (1979) Consideration in the earthquake-resistant design of earth and rockfill dams. Géotechnique 29:215-263

Strayer LM, Erickson SG Suppe J (2004) Influence of growth strata on the evolution of fault-related folds-distinct-element models. in K.R. MaClay, Thrust tectonics and hydrocarbon systems, AAPG Memoir 82: 413-437

Strayer LM, Suppe J (2002) Out-of-plane motion of a thrust sheet during along-strike propagation of a thrust ramp: a discreteelement approach. J Stru Geol 24:637-650

Taboada A, Chang KJ, Radjaï F, Bouchette F (2005) Rheology, force transmission, and shear instabilities in frictional granular media from biaxial numerical tests using the contact dynamics method. J Geophys Res 110:B09202. doi:10.1029/2003JB002955

Taboada A, Estrada N, Radjaï F (2006) Additive decomposition of shear strength in cohesive granular media form grain-scale interactions. Phys Rev Lett 97:098302. doi:10.1103/PhysRevLett. 97.098302

Taipei Observatory (1942) Report on Chia-Yi Earthquake on 17th December 1941 (in Japanese). Taiwan Governor's Office. p 227

Tang CL, Hu JC, Lin ML, Angelier J, Lu CY, Chan YC, Chu HT (2009) The Tsaoling landslide triggered by the Chi-Chi earthquake, Taiwan: insights from a discrete element simulation. Eng Geol 106:1-19

Varnes DJ (1978) Slope movement types and processes. In: Schuster RL, Krizek RJ (eds) Landslides analysis and control: U.S. National Academy of Sciences Special Report 176:11-33

Wang C, Tannant DD, Lilly PA (2003) Numerical analysis of the stability of heavily jointed rock slopes using PFC2D. Int J Rock Mech Min Sci 40:415-424

Wieczorek GF, Willson RC, Harp EL (1982) Map showing slope stability during earthquake of San Mateo County, California. U.S. Geological Survey Miscellaneous Geologic Investigation Map I-1257E, scale 1:62,500

Wieczorek GF, Wilson RC, Harp EL (1985) Map showing slope stability during earthquakes of San Mateo County, California. U.S. Geological Survey Miscellaneous Geologic Investigation Map I-1257E, scale 1:62,500 
Wilson RC, Keefer DK (1983) Dynamics analysis of a slope failure from the 6 August 1979 Coyote Lake, California, Earthquake. Bull Seis Soc Am 65:1239-1257

Wittke W (1965) Methods to analyze the stability of rock slopes, with and without additional loading. Rock Mech Eng Geol Supp II:52-79

Working Party on World Landslide Inventory (1990) A suggested method for reporting a landslide. Bull IAEG 41:5-12
Yeng KT (2000) The residual strength of Chin-Shui shale in relation to the slope stability of Tsao-Ling. Mater Thesis, Department of Civil Engineering, National Taiwan University, Taipei

Yoon J (2007) Application of experimental design and optimization to PFC model calibration in uniaxial compression simulation. Int J Rock Mech Min Sci 44:871-889 